\title{
UNIVERSITIES OF THE MUSLIM WORLD IN CONTEXT OF GLOBALIZATION
}

\author{
* Dr. Maroof Bin Rauf, Assistant Professor, Department of Education, University \\ of Karachi, Karachi - Pakistan (maro_of@yahoo.com)
}

**Dr. Mamnoon Ahmed Khan, Incharge, Department. of International Relations, Federal Urdu University, Karachi- Pakistan (mamnoonak@ gmail.com)

\begin{abstract}
This article expects to discourse the fundamental matters in regard to the emergency in advanced education in Muslim nations and investigate conceivable pathways for change. Notwithstanding being tested by the developing hole in instructive guidelines and accomplishments between exceedingly industrialized countries and Muslim nations, most Muslim social orders keep on producing fair outcome in advanced education. It's clear in most recent world college ranking, advance significance to evaluate the effect and difficulties of globalization on advanced education in Muslim social orders addressed in this article and additionally the main drivers of the emergency of advanced education in Muslim social orders, bad administration and insufficient governmental strategies lie at the base of the emergency.
\end{abstract}

KEYWORDS: Islam, University, Muslim World, Pakistan, High Education, Globalization.

\section{INTRODUCTION}

Modern development, along with promotion of cooperation between the societies developed the field of transportation, information and broadcasting and humanity welfare whereas universities to acquire the global status of the global harmony, mutual understanding and exchange of ideas among the countries. Universities where invites the students of different countries but there also exists the global trend of sending their own students in the universities of abroad. According to an estimate china is the leading country in the list of countries which send their students abroad for studies. In the last decades of previous century, not only the 
number of abroad studying student was increased but there was also an increment in the foreign teacher in universities.

\section{EDUCATION AND GLOBALIZATION}

Twenty first century was started with the rapid the advancement in the field of technology and with a flood of information. With the revolution in the source of access to information had changed our way of life. The explosion in the field of information and technology is so much intense that so many technologies and tools are activated when they even had not reached the market of third world countries. The fast track life of twenty first century requires special skill from us. It is most probably possible that the syllabus and skills of twenty first century was different according to their fields. Technology had taken thoughts to advanced level and develops new devices and services to solve new problems of life.

In 21 st century mutual cooperation means to work with other in such a respectable way that effective solution is find out by using mutual understating. One of the required skills of $21^{\text {st }}$ century was to reach, select, analyze information using different resources and ways of acquiring information. Effective use of technology means to acquire information by applying a suitable technology and an effective, useful and manner fully acceptable way for acquiring knowledge analyze information and spread information to others.

The syllabus of twenty first century emphasize that students should be proficient in such skill that makes them confident and self-sufficient to molded with the circumstances and make them responsible worker who could be capable of establishing a plan and work on it and can accept their responsibility of work and can make examples for the other and can establish work full ideas. The journey from localization to globalization was covered by cultural awareness culture awareness aimed to build such qualities in students that made to understand and respect culture difference when they work with the people of difference culture and social aspects. It is un-doubtable that education had is the first step towards implementable, dynamic and permanent economy. After the advent of internet nations had driving their attention to the value-added knowledge and skills. In this era of internationalism and nationalism countries were focusing on the international competition of education. This scenario accentuates students to take out most advantage of chance of learning international education through internet so that they could make their self-ready for international 
market. this was the time that student prepare them for international competition. Typically, our education system did not provide global access for education, but this era of internationalism had changed the situation for the educational institutes and students, so students should have equipped them with twenty first century education and skill so they could compete with surrounding world. Competition is the basic condition for today's world education. Development in the globalization and international economy resulted in the shape of international competition which was the shaping the education sector all around the globe. Presently we were living the world which seems to us a new and brave world but for our children it was just a world. Today we saw advancement in technology with respect, but our children hardly praise about latest development of technology. They require more developed technology.

Today our children were living in a life which can be defined by surrounding media like cell phone, mobile devices and other similar things. Digital media is considered interactional where user invent anything and it then spread like a virus. Children are rapidly using media for home work, expression of their thoughts, to talk with relatives and to communicate with surrounding world, by which world had actually gained- the shape of global village.

As today the lives of our children were surrounded by digital media and information and education that they acquire is termed as digital education. Which means to use technology in proficient way to understand digital material, to explain it by assaying its reputation. This is the ability of children to use suitable digital equipment for invention and broadcast communication. Digital education is the important part of twenty first century education where students are taught inventory approach and judgmental thinking. in this digital era, digital education shapes the concept of digital citizenship which means that children accept their responsibility of their upload material and activities on internet, cell phone and other similar things. The weakness and vastness of digital media require proper legal rules and moral regulation should be set for its usage. For dynamic digital media we need new understanding, communication skills and usage rules which could assure children safety while they use this digital strong digital media. We just wanted these technologies should be in responsible and ethical way. We know that digital world was the world of distances which act on the principle of action had reaction which made it a weak place for illegal and un ethical activates. Our children had born in the technological revolution which is incredibly affecting our 
children life's. children are spearing more time in texting, chatting, watching movies and playing games rather than with their parent, friends or spending time at home. digital world had closed the world in the palm, which give access to large source of information in this situation the material uploaded by the users is affecting our children physical, mental and social growth, so we parent are standing on the sensitive line of dangers and possibilities. Another problem is that some of us are not aware of these new technologies so it is not possible for us to look after our children information access. People of $21^{\text {st }}$ century, are surrounded by technology where their approach is just towards the technology and increment in technology and due to this reason they can makeup with the basic needs. $21^{\text {st }}$ century is full of criticize thoughts due to which respect of technology is found in knowledge. It is important for students to learn information so they can analyze information critically and professionally.

Students should know to solve problem faced when they use information correctly and inventory way. In this era of twenty first century globalization students should have profound knowledge of media so they could understand the motives of messages from the media. They should have the ability to understand how other can judge that how can people covert and explain different messages with or without their own purposes and values. They should also be aware of that how media is influenced on in devout and manners. And they should also aware about all accepts related to media and its uses. Students of $21^{\text {st }}$ century should attentive about media and should be responsive about uses of tools of media and should know that how to present this in proper way with respect to civilization. Student should use media for education purposes or for gaining knowledge and they should use media tools for gaining extra knowledge and help in increasing the economic growth.

Creativity and innovation has close relation in between and their meanings are also mixed. Short note is expressing untouched but excellent thoughts of someone. And innovation is about understanding that thoughts, work on it, prepare proper budget of it and give it a face of reality. Creative notes work as a fuel for innovation. That's why organization should establish culture where untouched thoughts would build up and where the importance of these thoughts would judge with respect to innovation. World is running fast and so as innovation and creativity school should provide students that environment where they can play with creativity and innovation. 


\section{HISTORICAL BACKGROUND OF UNIVERSITIES}

University is supposed to be that place where students are tough practical application of theories. To find hidden talents and to spread them is work of universities. Universities is Latin word, which means is some kind of cast. This word university is derived from word "Unistas" and now this world is leading on English. The history of university is started from $12^{\text {th }}$ century at that time Christianity was on peak that's why students and teachers made France and Italy their cultural place and visit their they made it their cast. They were of Cristian world peoples and they asked Pop to register them so pop did. "At that time university becomes an institute besides being as a management place".(Institute of Policies studies, 1995:13)

In the universities of starting ages, it was their responsibility that they define their rules and regulation by their own, they legal separate entity from local management and was closer to religion. It was a stable system where universities had their own lands, gardens, buildings and permanent staff. They present their own rules.

"In $13^{\text {th }}$ century many universities worked as a legal body. With the changes and evaluation continues with time and approximately in $14^{\text {th }}$ century universities grooming was implemented. In 1209, Cambridge university was formed in the result of transfer of students from oxford university and 20 years after this in 1229 the students who transfer in Paris again started oxford university". (Institute of Policies studies, 1995:89)

If we try to focus present university are doing same works for which universities was established. Means they promote education which includes teaching and training. They determine the high-quality education, issue degrees, and they are basic research institution where the highest research had been done. But the difference is that today's universities are present under the laws of their country While the universities of early era were contrary to it. Locally universities nominate bishop as the chancellor because he was the repetitive of the pop. As a result, the local bishop started interrupting their issues due to his closeness. So, an institution was established in universities named rector. Reactor belonged to the Pope in the same way as before the Universities had given it to bishop. This relationship was in the interest of both universities and Pope. In this era the church had an autonomy in religion in the European states. However, due to be a privileged institution or class, the universities system went into a downfall within a century. 
Even until the twelfth to the 15th century, the un interrupted university and pope's relationship becomes stressful and a Collison occur between universal freedom and Pop/church interruptions.

During 15th century, the renaissance movement started in west which aimed to search and study Greek knowledge. The Greek society in their historical period was drowned in worship of gods and Heathenism. which also effected their promoted knowledge. While Christians knowledge was contrary to this. Therefore, this movement created two distinct effects. One of the most commonly developed ideologies, the other church was weak. For the convenience of the century, take these ideas into a church within a church that is called a peace system. Now the beginning of conflict is primarily Christianity and liberation. The real perception of materialism that the earth was of matter. The real feature of universities was to find those peoples who could change the thinking of society with their knowledge. (Abdurrasheed, 1995:24) This is how the universities help in the development sometimes government supports them and that how universities developed.

\section{HIGHER STUDIES AND GLOBALIZATION}

The definition of higher studies in normal perception was the study of universities but the real definition is. In England the term 'Higher Education 'has no specific legal meaning defined in an act Parliament. From 1902 to 1944 there was a statutory meaning of the term but it meant (broadly) what we now call Secondary Education. (Larry,2007)

So that's proof that higher education started from college level and Pakistan gives inter level education in colleges and they also provide graduation level education in colleges which is known as "degree colleges ". Here universities enrolled students for both degree and inter levels and award them with different degree of M.Phil./ $\mathrm{PhD}$ etc. Universities of course are in some respect to many other forms of large organization. They consist of

People money materials and buildings the use of which must be managed in order to accomplish the functions and objective of the institution. (Majid, 2000)

Universities are not just a big asset due to large number of people, building and money they have their own scale universities make 
individual stable and they also helped in the development of a country. In 1975 , the statics of students who went abroad from studies was 8 million, Increased in 2004 to 40 million. In $20^{\text {th }}$ and $19^{\text {th }}$ century, the students prefer to get higher education from developed country, and by this the concept of making their branches in other countries increases and this is very helpful for those students who could not afford the expense of studying abroad so, they can live here and can get higher education in their own country. By the research of everyday news week, the university branches outside the country have right to make students their ambassador specially those countries where west is looked with the doubt.

The globalization of economy has led to internationalization of higher education, not merely for economic benefits, but also for increased social interaction and promotion of international understanding. A stage has reached that higher education in not at all different from any other commodity can be bought and sold at the marketplace. (Annabelle \& Betsy, 2007)

Whereas the higher education institutions, and universities, have extended themselves to this process Global economic and economic situation also universities which also helps in the development of economy.

\section{MUSLIM WORLD AND UNIVERSITIES}

Universities bounded professors and students and due to this they are separated with the world. The universities have performed best in all aspects, but due to their traditional system the relationship has been minimized from their surrounding and they surround themselves with their own thoughts. The way to fully utilize today's modernized universities is to get acquainted with the necessities of the modern world and make their student the part of the society. If we review as compared to the Muslim countries, in the developed countries universities methodology and curriculum we found the feeling of fulfilling their needs of society. The use of resources available as a consequence of the emerging population of the world is an important necessity, and the most important resource in these resources are these universities and today they have to play a vital role in this society. So, investment in higher education is same as we are investing for student's future. And by achieving some goals universities can provide their best to the societies. Some of them are. 
1. Research on the achievements of the Muslim world and the objectives of the development of the Muslim world

2. The Muslim world can communicate lifetime between the universities, public and the politicians

3. Research on issues related to real world and development needs of the Muslim world

4. Applying this case according to the local needs by making global issues available

Today, society around the world grows according to the social and economic situation and requires some things regarding this development. For example, society is ready for constitutional matters that can affect their height and objectives. Secondly, the society allowed compulsion to play their role in establishing goals We can say that the leadership of things regarding the goals and powers is the work of political institutions rather than the universities. But the religion of the Islamic world can prohibit the material and the basis of these things $\mathrm{He}$ can communicate and discuss the matter where the forum is to be noticed. A Muslim society can only be able to agree with its universities, when society and universities are combined together for the development and development of the Muslim countries. Through this specific process, it is possible that universities of the Muslim world can come out of their traditional parts and contribute to the development of modern Muslim society. (Abdallah,1984)

\section{UNIVERSITIES OF MUSLIM WORLD AND THEIR RESPONSIBILITIES}

Commonwealth in universities in the world is understood that they have to create individuals through the level of Master and PhD. But this is just the work of their explicit level. What is active in compassionate, it is a home of research, and for that matter, it is responsible for the youth to collect the matter. They face the changing world's problems and challenges, expecting the community and designation of students' needs on day-by-day.

Some responsibilities of universities are as follows.

1. The responsibility of the universities is to enable people to get the best in their sector because it can be a jurisdiction where it is 
necessary to step out of its own life and step in his professional life.

2. One of the main responsibilities of universities is the preparation of specialists for various fields.

3. No country can develop until it has mutual cooperation and partnership in its institutions. Universities also involves students in extra activities.

4. However, the university is the last stage of studies but it also teaches you the basics of first stage. Ethics, management, administration everything will be the topic of your professor's lecture.

5. One of the most important responsibilities of the universe is to support the country's society in the social stability and play their role.

6. Similarly, according to the Islamic concept of human being, it is also the responsibility of university to hold a program here in the present era of internationalism that can be influenced the nonMuslim world and they follow Muslim countries like they follow other countries.

\section{ISLAMIC WORLD, ECONOMIC DEVELOPMENT AND UNIVERSITIES}

Today, the Muslim world's educational institutions are considered as a capital investment in human resources. Increasing the quality of individual and society, those countries of the world who have grown rapidly in the past 25 years, have been mainstreaming their education and education. Depending on the growing population, the development of especially developing countries depends on how much they utilize all their sources.

The most important source of development of any country is universities depend on the development of nations generally two ways one is growth and second is change if considered, these two actions are possible only through universities. The whole benefit of universities in the Muslim world is also possible that the societies belonging to the Companions. In addition, the combined needs of the universities activities will be possible to achieve social goals. In this respect, the role of sustainable countries is not a necessity of any introduction, therefore, it is highly responsible for universities of particular countries that they are able to develop a bridge between them and their nation. 
The role of the universities is the most important for the development of the country in relation to higher education related to social needs and expectations. In this way all communities of society have the equal opportunity of emergency and practical issues. Education and especially for higher education cannot be separated from social background, spiritual needs of the higher education objectives society are deeper than the financial needs. In the present era, no country or society can think of development unless its higher educational institutions or universities are in accordance with the social needs of the society.

The current Muslim community adds to the rapid increase in the use of all the sources of state-owned resources in order to be organized and configured. The role of Pakistani universities has been very important in civilization, especially if we analyze the big cities of Pakistan Karachi, Faisalabad Rawalpindi and Peshawar they need to get involve in country level association. These cities are facing a lot of problems, not having good health, inadequate food traffic jams pollution so that these students are paying their best and universities should also look after this. With the low rates of students studying in the universities of Muslim world, it is evident that it was not given attention to its courage on donated education. It is a scientific fact that human society is not only for development of survival, the need for higher education is also needed. According to a research of the World Bank, material investment in the state is only 16 per cent. 20 percent of natural resources include 46 percent to human resource and social basis. Those countries who has invested more on higher education, he is recognized as the world's lion. Pakistan did not invest that much on higher education. Therefore, in the era of development, we are at the end position, it is imperative that the Muslim world invest more in the development of human resources so that it is the community could develop more. (USAID: Washington, D.C., 2004)

Education and especially higher education cannot be separated from their mother and social background because the goals of higher education are a deep connection with the spiritual and physical needs of society. Today, no society and country cannot imagine a little bit of development without education. Despite the increase in the number of educational institutions and universities in Pakistan the students are just 5.1 approximately 11 million. By this table we can assume that how much countries invest on higher education. (The United States Department of State, 2002) 


$$
\begin{gathered}
\text { Pakistan }=5.1 \\
\text { Bangladesh }=7 \\
\text { Indonesia }=27 \\
\text { Malaysia }=40 \\
\text { Turkey }=70
\end{gathered}
$$

\section{SOCIAL DEVELOPMENT IN THE MUSLIM WORLD AND UNIVERSITIES}

This thing is proved that the individual development of society is the main reason of countries economic development. So, the country will have economic benefit by any individual's economic benefit. Higher education has very big relation with economic development. Those people who are linked with (OPEC) their education scale sis $51 \%$. In comparison to this, it is only six in average income countries and 21 in low income countries.

It also shows that poverty reduction in the cost of higher education increases the production capabilities of labor worker's Longterm financial growth is an important part in promotion. (Esposito, \& Mogahed, 2007).

In the 1960s and 1970s, whenever a lot of research was expressed in the context that higher education was less than elementary education. And because of this it was anxiety that equals higher education, so there is public interest in comparison to higher education. In view of those investigations, the World Bank from the institution also restricted the policy of taxing in developing nations to elementary and secondary education only and ignored higher education. However, in 2000 where academic societies have changed There are strong arguments regarding higher education regarding the new research in the World Bank report, and the prevalence of previous learned referee denied. Without well-educated there is no possibility of excellent government and developed infrastructure facilities. Therefore, the long-term interests of the society are in higher education, which is far beyond the interests of the people. (Inglehart, \& Welzel, 2005).

Thus, the role of universities in the economic development in the World Bank's Report "Higher Education: lesson of experience" The role of universities in economic development had been described in these words. It has a great deal of importance in higher education. The main 
responsibility for education institutions is that they can keep their people aware of modern science and arts People are required to pay duties in governmental and professional institutions. In these institutions knowledge is increased through research. It is a work that leads to promotion and promotion. Support through the social services in the government and trade sector. By expanding national identity in noncountries and making anxious exchange of views on various issues Educational institutions are performing important services in the economic and social fields. (The World Economic Forum, 2007)

The general publication of education in the Muslim world resulted in social development and the development of society in three stages

1. Regarding any production and founder of the workers working on them a secondary pass worker is more eligible than two primary pass.

2. In such a way, there is no alternative to any engineer by combining thirty work hard work in a place. For instance, Aircraft higher less educated persons as compare to educated persons because the need of this field is this.

3. We know that technology is a permanent change, and after a while it comes to a new version of things such as high-trained man diagnostics. As a result, the role of all these people is not the same as a user or certificate, but the technology creates more technology as a consequence.

Today, the education sector is significant contributor of foreign international diploma and degree studies that were previously available in the region. (Talukdar, 2003).

Like the universities of other countries, it is a part of the role that can create the universe of the Muslim world but the question arises how it will be possible. how our universities will be able to update the technology and to improve the age range for better results of such many important issues. In which they could heir teacher with high wages. And to provide safe and sound environment to students and teachers and help their children in their choice and character building even they help them when any political hurdle came in their place. Japan, Germany, America, China, and many other countries like them proved that development of any country based on Higher education. Those countries proved themselves 
with higher education and now many people want to get job there. With respect to this topic the relevant example is of Korea which was in 1960 at the lowest stage of Asian countries but in 1990 it got rapid development. When in 1960, Pakistan were spending only $1 \%$ of its GNP to higher education, Korea was spending double and Singapore was spending triple of its GNP on higher education. These countries got benefit in shape of human capital y investment in higher education. by the survey of Pakistan and Korea in 1967-1993 both countries were at same scale. (Elmore,1995).

\section{ISLAM AND UNIVERSITIES}

Islam emphasize on an occupation to live life. Prophet Mohammad (S.A.W.W) sometimes said earning is superior and sometimes said that a higher hand is better than the lower. It self Sahaba Ikram were stick to an occupation even Our Prophet SAWW was from trading occupation. Islam emphasize to get education in that era when darkness of illiteracy was common and now every occupation is related to higher education. Prophet Mohammad SAWW /said to all new Muslims to get education from the lap of mother to the darkness of grave and said them to even go out of their country for getting education. Prophet Mohammad SAWW said that educated person is as a full moon among all stars and moon.

Orientation of the nation and worship of the universe, on the other four stars of the fourth in this way, teaching this great work, the personality of education and the degree of corruption and the best man. In the same way, after reaching this time, it is not known to be a scholar of the knowledge of its fulfillment. Then the next day the iron will be poured out in its mouth.

The beginning of education was started with the invitation of Allah's Messenger and the first place was found in the academic mosque, As the first lesson was during Madrasa and Masjid, the court where nine Muslim issues were learned. The teachings of preaching of religion were brought to Sharia, in the hundreds of hundred years of the real light of Islamic education. Mediars were established in the Freedom of Peace world, including Spain and Chile, not only the local countries used to adhere to almost all the regions of Europe. The teachers established in all the cities of Spain were very famous. Students from the seminaries went to Europe and they flourished in their country. And thus, the vocabulary of thought of Islamic teachings spread out and the external attacks carried out 
knowledge and action The way you get rid of the guilt is your example, from which since today the eyes of every Muslim are aware of the general status of the scholars and scholars of the world apart from today. In the time period of second Caliph when new mosques were being made and second caliph scheduled companions of the prophet for teaching rules and regulation of Islam. In the era of all caliphs, they focused Arabic language especially Arabic poetry. In this mosques except of social and religious issue, global life issues were also being talked. some of famous mosque of that time are masjid ul haram of mecca, medina munawara of Medina, Jamey masjid of kofa, misar ki jamaye umro, betulmuqadas kii masjidey aqsa. A historian in the third century said, that there are three thousand mosques in Baghdad. The thirty-century century Angels Tourist ibn Gabriel explains that the number of madrasas capable of measuring twelve thousand mosques in Alexandria Egypt can be estimated. In this era, large education institutes in all Islamic countries were taught higher education in the current universities. For example, Arabic knowledge, narration of the Hadith, physics, philosophy, history geography etc. Muslims created big thinkers whose experiments are also using non-titles, those thinkers need to comply with knowledge society. Imam Ghazali seprated education in two expects. (Institute of Policies studies, 1995:89)

Assurance: definitely obligatory on every Muslim, such as the words of the martyrdom of the fasting and the other essential religious things

Compassionate: The knowledge that is necessary for human society, but by learning a few people needs the society to be fulfilled.

In that compassionate compulsory two subjects are included:

1. The Religious: which includes not just Arabic, language, interpretation, hadith philosophy, Al-Qalam, art of recitation, logic, the jurisprudence etc.

2. The non- Religious: which includes medicine, math, agriculture, political science, the work of the barber, text book, the work of the tailor, and includes other science and arts just like that ibn-ekhuldoon declares education as an industry because its development is just like an industrial development just like an industry flourishes in a city education also stirred in the same environment. (Shabbir, 1978), 


\section{SUBCONTINENT AND UNIVERSITIES: -}

Sultan tipo Shaheed (1799) was the first Muslim leader who established a western style Jamya in suringham pump with the help of Frenches and named it "Kul unmoor". This word is the translation of the university name. In 1918, after the establishment of Usmania University in Hyderabad the word "University" was spoken in terms of the word "Jamia". (Institute of Policies studies, 1995:53)

The proper start of universities in Southern South Asia took place after 1857. British Indian government established universities in Kolkata, madras and Mumbai and made the university of London which at that time was just an examination university as a sample for these universities. (Abdurrasheed, 1995:147)

The government of British India established universities in Kolkata, madras, sawar and Mumbai. In the current boundary of Pakistan, the first educational institution was established in Lahore in 1882 named Punjab university. although the approval of Sindh university was given before the creation of Pakistan the university was made after the creation of Pakistan in 1947 at Karachi which was then shifted to Hyderabad and then Jamshoro. (Institute of Policies studies, 1995:89)

\section{CONCLUSION}

At present keep looking on the universal requirements the Muslim world universities have individuality over other countries universities because these are the universities of that country which came into being after the independence movement whose aim was not just to have independence from another country or to have a piece of land but through that Muslims after 200 years' slavery expressed their collective expression that they wanted to live their lives according to them believes and values. therefore, at this piece of land which we got after lots of lives and properties sacrifices, we don't want to establish common universities but we want to make them the center of world movement which was the continuation of the movement of Pakistan and these universities under a natural process play a role through which whole environment.

An example and support was made after the independence of western universities before the distribution of the subcontinent. Although the education of English colleges and universities established in India was not a very standard education, the education given in the country was the 
worst way to educate themselves as an occupation. Whose goal was to prepare the same mentality clerks to continue the occupation of the crown of the Brittan. There is a possibility of objection to the fact that because of them educational institutions have been given courage and equality to the movement of Tehreek-e-Pakistan, the movement of Pakistan that the concept of a Demonstrator The second question is that two different things and facts appear to be proven as described above. Similarly, scientific devices are imported from Europe, which cost too much but never tried to be made locally because it would have affected Britain's trade Teaching doctors to medical academics teach that the agricultural education institutions in the suburbs were very fertile, due to the urgent need for change and development of old ways. However, the British government has certainly established agricultural education institutions, but instead of entering farmers or their children, entering middle-grade rich children, it was given to electronic tools. But they were interested in getting jobs in the departments of the government departments, so that they would get jobs, but agriculture did not get any development, almost the same as other educational institutions. In these universities and those who came out, it was not possible to handle the race of the country, but the theory came to pass against the act Everywhere the people were prepared to make professional education jobs in the government departments no effort to comply with the country's industrial needs. Why does not the Muslim world have to be naturally involved in reasons, it is also important that no destination has been set for Jamya. Other facilities increase in the rise of new faculties and efforts to improve western universities. At the time of Pakistan, the University of Punjab was able to meet the educational needs of all country except Sindh. Sindh University's education system was similar to Chowk Bombay University and it is established in 3 April 1947. Initially the slowdown of the growth of Pakistani universities was but almost seven years later there are now doctorate level studies are also available in many courses. If there is an awareness in the background of the promotion of higher education, it is known that the number of jurisdictions in the first decade after Independence was limited to 4. then 6-degree -making institutions have increased after that in 1968-1977 they increased to 18 and then in 1978-1988 to 26 and from 1998 to since today they have become 132 which is a record degree giving institutes. Convert Muslim world-class education institutions into universal education centers that create an enormous role in the promotion of advanced education and development. Which is a strong moral character. It is imperative that the Muslim world to invest more in human resource development so that it is honored in the community of the universe. 


\section{RECOMMENDATIONS}

- Develop a global forum regarding universities of Muslim countries, especially in the Islamic context, to encourage professional education and research.

- Educational visits and scholarships should be arranged for the students of Muslim counties.

- Visiting lectures of renowned scholars of Muslim countries.

- Ask industries and educational institutions to investment and employment in their respective fields.

- Like Australia, Muslim countries can also bound their industries to spend a certain part of their income on student training and research activities.

- Like Malaysia, Muslim countries try to establish universities in their corporate sketchers and national ministers and provide jobs to their students in the respective fields.

- $\quad$ OIC should be enabled in this regard. 


\section{REFERENCES}

Abdurrasheed A. (1995). Evolution of Education in Pakistan.Institute of Education al Research, Lahore.

Abdallah M. Z. (1984). El- Ta'lim fi al-Mamlake el-Arabia el-Saudia: AnmouzgMukhtalif, 113-123

Annabelle M. \& Betsy E. (eds.)(2007),Globalization: The Key Concepts, New York: Routledge, $\mathrm{p}-4$

Elmore, R. (1995). Structural Reform and Educational Practice. Educational Researcher, Vol. 24, No.9, pp. 23-266.

Esposito, J.L. \&Mogahed, D. (2007). Who speaks for Islam?: What a billion Muslims really think. New York: Gallup Press.

Institute of Policies studies, (1995) The Role of Universities in Pakistan. Islamabad.

Inglehart, R. \&Welzel, C. (2005). Modernization, culture change and democracy: the human development sequence. New York: Cambridge University Press.

Larry R. (2007), Globalization and Everyday Life.London:Routledge, pp. 1-4 Majid F. (2000) Islamic Philosophy, Theology and Mysticism: A Short Introduction, England: Oneworld Publications, pp. 6-10

Shabbir A. (1978), Story of Education, Kifayat Academy, Karachi, p-232

The United States Department of State (2002).Office of Religious FreedomReport,http://www.state.gov/g/drl/rls/irf/2002/1360 8.htm.Accessed in July, 2014.

The World Economic Forum (2007) "Islam and the West: Annual Report on the State of the Dialogue"

Talukdar, M. H.R. (2003). Science in the Sublime Morals and Maneers of Prophet Muhammad (SAW), G.P.O. Box 10066, Kuala Lumpur, Malaysia, Published by A.S Noordeen.

USAID Bureau for Policy and Program Coordination, (2004) Strengthening Education in the Muslim World.Country Profiles and Analysis. Issue Paper Number 2. (USAID: Washington, D.C., 2004). 